\title{
Selected Impulses of the Synods of Bishops on the Family $(2014,2015)$ and of the Post-Synodal Apostolic Exhortation Amoris laetitia (2016) for the Helping Professions Jindřich Šrajer
}

The two sessions of the synod of bishops on the family of autumn 2014 and 2015 and the post-synodal apostolic exhortation Amoris laetitia by Pope Francis on love in the family of spring 2016 are without doubt one of the most significant events or enterprises in the recent life of the Church, especially since they focus on one of the crucial issues of the present time. The presented outputs as well as the way in which they were reached ${ }^{1}$ have given rise to numerous controversial reactions. ${ }^{2}$ On the one hand there are fears that the traditional doctrine of the Church on marriage and family has been set in doubt, or fears that the Church has unacceptably conformed itself to the spirit of the time and diluted the ideal of conjugal and family life it had previously proclaimed in a false effort to help people who have failed in their sexual, conjugal or family life. On the other hand there is joy arising from the openness with which the Church faces the problems of the present times, from its courage to openly name the problems of conjugal and family life, and especially to approach those who have stumbled and are still stumbling on this path with sympathetic love. $^{3}$

The two synods and the papal document Amoris laetitia seek answers to the burning and increasingly more pressing problems of families exposed to numerous difficulties and pressures, including efforts at their very destruction. The synods and the papal document offer a number of incentives, both for the form of the Church's pastoral practice and for social work. Pastoral work is not aimed merely at solving problem phenomena in conjugal and family relationships, but also at their prevention. Social work systematically focuses on problem phenomena in these spheres of life. The difference between these two practices consists in that pastoral work with married couples and families derives from the principles of Christian faith, while in social work this is neither a condition nor a general standard. This very fact gives rise to the question of to what extent and whether at all the incentives contained in the output documents of the two synods and in the post-synodal apostolic exhortation can be inspiring for social work, since they derive from the Christian worldview and assume it in the interested persons. The presented treatise implicitly

1 Cf. on this Heiner KOCH, Amoris laetitia. Eine Erläuterung, Stimmen der Zeit 6/2016, pp. 364-366.

2 The spectrum of different evaluations of the document Amoris laetitia does not follow the simple schema of progressivists versus conservatives. The spectrum is much more varied. Cf. on this Walter KASPER, „Amoris laetitia“: Bruch oder Aufbruch?, Stimmen der Zeit 11/2016, pp. 723-724.

3 Cf., for example, Jindřich ŠRAJER, Nad synodou s nadějí, Universum 1/2015, pp. 36-37. 
touches on this question by specifying the particular incentives, or their practical significance for those two practices, which is preceded by a brief overview of the form and significance of the Christian ethical paradigm in Church history.

\section{The permanent task of the Church - to re-formulate and substantiate the values that are proper to the Church and constitute human meaning}

In order to offer a reflection of the presently possible contribution of the Christian ethos, as formulated in the abovementioned documents of the Church, to cultivating married and family life and to improving the quality of pastoral and social work with families, some essential facts ought to be mentioned in this context.

The Church, which the Second Vatican Council conceived as the People of God wandering through history, is on the one hand the bearer of immutable divine truths. On the other hand it is a part of secular society, with which it shares its joys and hopes, griefs and anxieties. ${ }^{4}$ Thus the Church not only attests to the divine origin of marriage and family and to the notion of the character of successful conjugal and family life as approved by the tradition and confirmed by Church authority, but is also repeatedly confronted with the permanent task of re-formulating and substantiating the values that are proper to it and constitute human meaning. ${ }^{5}$ It is also necessary to mention its historically conditioned situation and roles and the frequently associated form and significance of its ethical paradigm in society.

It is a well-known fact that many religious precepts, as they are known, for example, from the Old Testament, are mere sanitary norms or regulations ordering the functioning of society. They are intended to guide the person to a healthy life, to a peaceful and just formation of relationships in society, to its proper functioning. In religious societies, osmosis between the secular and the religious, the worldly and the ecclesial, inevitably occurs. The religious or ecclesial paradigm permeates the entire society and determines its character. It affects all of its members, for whom it becomes an inseparable part of their everyday life. In Western European history this important role was taken for a long time by the Catholic Church, which held a dominant position in this respect. It guaranteed the homogeneous character of society and watched over its morality. But it was not always the case. To a great extent, its paradigm concerning married and family life copied the social circumstances and conceptual schemes of the given historical period and at the same time it often arose as a particular reaction to a problematic life practice.

The foundation of Christian life practice is fulfilling the requirement of faithfully following Jesus Christ, which, among other things, not infrequently means being 'a sign that is spoken against', contrasting with the socially and culturally dominant life practice. That held especially for early Christianity, but without doubt still holds today. ${ }^{6}$ In its beginnings, Christianity brought critical incentives regarding the family and individualistic-emancipating impulses into ancient family societies and their life practice. ${ }^{7}$ Jesus confirms the original creational intention regarding marriage as a unique and indivisible community of a man and a woman (cf. Matt 19:3-9). With his teaching and attitudes he appraises the value of marriage (cf. Matt 9:15; 22:1-14; 25:1-13; Jn 2:1-12), and 
the dignity of man and woman. But at the same time he relativises the exclusive position of marriage in the Old Testament. ${ }^{8}$ He de-emphasises the traditional family relationships in own family (cf. Matt 12:46-50; Matt 8:21). With his teaching he disrupts family relationships (cf. Matt 10:3436). When the first Christians ask about the justification of marriage and the way of experiencing it with respect to adopting the Christian faith, they receive a temperate, yet specific answer in the form of a few recommendations and pieces of pastoral advice (cf. 1 Cor 7 ).

The ecclesial paradigm concerning conjugal and family life, which had for a long time been characterised by stability of 'the house' (extended family) - 'integrity of "the house", community and place' and associated with an undoubted stability conditioned by economic interests and characterised by the cohesion of generations, married couples and parents with children, ${ }^{10}$ was 'conserved' in the New Testament period in debates and doctrine on the purpose of marriage. Conjugal and family life were, especially under the influence of Augustine's teaching on marriage and the goods of conjugal life, ${ }^{11}$ one-sidedly, if not exclusively, appraised as providing a service to life. The value of the partner relationship was underestimated or not reflected upon. ${ }^{12}$ This dogmatic momentum in the Church's doctrine on marriage, which had been maintained for a long time, was unshaken by the oncoming changes in social circumstances occurring especially in the period after the French Revolution and the beginning of the Industrial Revolution. These changes, which consisted especially in reinforcing the significance of conjugal intimate life, the conjugal relationship and changes in the family's function, were disregarded by the Church, which resulted in a weakening of its social status and authority. Its message became increasingly antiquated in character.

A change in this respect was brought only by the Second Vatican Council (1962-1965) and its pastoral constitution Gaudium et spes (GS), which, while aware of the immutable (divine) origin of marriage and family, reflects on their updated significance in the context of contemporary social, economic and life circumstances. Marriage is presented as a community of love and marriage, with a balanced emphasis on the value of conjugal love and service to life. ${ }^{13}$ Although the fundamental change, as compared to the earlier paradigm concerning marriage and family, was not born easily at the Council, as manifested by some of the contradictions of the resulting compromise text, a new paradigm was nonetheless founded there, which is biblically grounded and characterised by openness to the contemporary findings of the natural sciences with the goal of veraciously grasping the contemporary reality in the sphere of marriage and family and to present an intelligible incentive towards an adequate experiencing of conjugal and family relationships. ${ }^{14}$

8 In the Old Testament marriage is a basic obligation to which there is no life alternative. Cf. on that Johannes B. BAUER, Ehe, in: Bibeltheologisches Wörterbuch, Graz - Wien - Köln: Styria, 1994, p. 112. In the New Testament the life alternative to marriage is virginity (Matt 19:11f).

9 Miloslav PRŮKA, Péče o oikos. Dưm v dějinách myšlení, edice Pontes Pragenses, vol. 55, Brno: L. Marek, 2009, p. 81. Lubomír Mlčoch, following up on what has been said above, point out the multi-dimensional meaning of 'house' (extended family), which 'included community of lodging, property, the broadly conceived family including patrimony, community of faith as well as the way of life and managing the household', which, as he correctly states, survived in the Czech milieu in many respects 'until the specifically conceived modernisation of "real socialism". Lubomír MLČOCH, Ekonomie rodiny v promènách času, institucí a hodnot, Studie Národohospodářského ústavu Josefa Hlávky, Praha, 2013, p. 7. On the character of the extended family cf. also Anton RAUSCHER, Znovuobjevení rodiny, ediční řada Ordo socialis, Brno: CDK, 1996, pp. 3, 5-6.

10 Cf. Anton RAUSCHER, Znovuobjevení rodiny, p. 4.

11 On Augustine's conception of marriage cf. Michael MÜLLER, Paradiesehe. Die Lehre des Hl. Augustinus von der Paradiesehe und ihre Auswirkung in der Sexualethik des 12. und 13. Jahrhunderts bis Thomas von Aquin, Regensburg: Friedrich Pustet, 1954.

12 In traditional Catholic moral theology and canon law, marriage is conceived as a hierarchical community of conjugal goods and ends. The highest of these, superordinate to the others, is the begetting and education of offspring. Cf. CIC 1917, can. $1013, \$ 1$.

13 Cf. Gaudium et spes 47-52. Cf. on this also Jindřich ŠRAJER, Nové pojetí manželství, Teologické texty 1/2003, pp. 17-19.

14 Cf. on this Jindřich ŠRAJER, O důstojnosti manželství a rodiny, in: Jindřich ŠRAJER, Lucie KOLÁŘOVÁ et al., Gaudium et spes padesát let poté, Brno: CDK, 2015, pp. 168-205. 
After the Council, the Popes Paul VI (1963-1978), John Paul II (1978-2005) and Benedict XVI (2005-2013) repeatedly emphasised the anthropological and theological basis of marriage and family. They underlined the natural character of these institutions, i.e., the fact that their truth is grounded in the truth of man. ${ }^{15}$ This foundation is then used to deduce the binding norms contained in it, which are to form conjugal and family relationships and the tasks implied by them (for example, in the sphere of the transmission of life). Benedict XVI tried to prove that the attitudes of Christian ethics are not far from general human experience, from the reality of this world and the issues associated with it. According to him, Christian ethics does not aim to suppress human values or expressions, ${ }^{16}$ but to bring a specific point of view into general human experience, which purifies it, transforms it, discerns and heals, elevates and in light of God's love brings to fulfilment all that is truly human. ${ }^{17}$ But at the same time it openly admits a certain lack of ability to communicate these values well to others, especially to young people, who in his words are afraid of a definitive decision for marriage and at the same time it is necessary to do away with their deeply rooted bias 'that Christianity with its precepts and bans poses too many obstacles to the joy of love, especially in that it does not allow them to experience fully the happiness a man and a woman find in their mutual love. ${ }^{18}$ In general it is possible to say that the abovementioned three post-Vatican II Popes primarily strive to present the ideal of marriage and family together with the effort to present this ideal intelligibly for human beings. In other words, the primary effort to perfect the ideal of marriage and the overt emphasis on the validity of objective moral law which needs to be observed at the same time means that not enough attention is paid to the frequently problematic and complex reality in which individuals not infrequently find themselves. In the ecclesial paradigm so far this seems to manifest a lack of appreciation for their responsible freedom or perhaps even a primary distrust in it.

Pope Francis follows up on the Vatican II and post-Vatican II doctrinal line regarding marriage and family, but of course brings in new emphases and incentives, establishing a new ethical paradigm. This paradigm does not evade a humbly self-critical evaluation of the former manner of presenting the Christian principles and attitude regarding marriage and family to people. The Pope speaks quite concretely, openly names the problematic attitudes and formulates new requirements with respect to presenting marriage and pastoral care of it. He is critical of the former overt idealisation of marriage, which according to him thereby becomes something abstract, unattractive and almost artificially constructed in the eyes of people. ${ }^{19}$ He thinks it is inexpedient to rhetorically denounce contemporary abuses, to take the defensive position the Church has so often taken in history, to waste energy on numerous assaults against the degenerating world and not place sufficient emphasis on pointing out the way to happiness. ${ }^{20} \mathrm{He}$ also holds that the Church's message regarding marriage and family did not clearly reflect 'the preaching and attitudes of Jesus, who set forth a demanding ideal yet never failed to show compassion and closeness to the

15 Cf. BENEDIKT XVI., Myšlenky o rodině, selection of texts by Pope Benedict XVI, edited by Lucio Coco, Praha: Paulínky, 2010, p. 24. Pope Benedict XVI corroborates this fact also by reference to the cultural history of humanity, which is marked by sin and by obfuscation of the original meaning of marriage, and yet the human being is still aware of the fact that all other forms of relationship (than marriage) between man and woman contradict the original plan with humanity. According to Benedict XVI, the great cultures again tend to monogamy, the community of one man and one woman who together are one flesh. Cf. ibid., p. 29.

16 See Nietzsche's criticism of Christianity, which allegedly gave poison to drink to the eros (bodily love) and degraded it to a mere vice. Cf. on that Deus caritas est 8 .

17 Cf. Joseph RATZINGER, Obnova morální teologie. Perspektivy 2. vatikánského koncilu a encykliky Veritatis splendor, Communio 3/2006, p. 307.

18 BENEDICT XVI, Myšlenky o rodině, p. 116.

19 Cf. Amoris laetitia 36.

20 Cf. ibid., 35, 38. 
frailty of individuals like the Samaritan woman or the woman caught in adultery'. ${ }^{21}$ Pope Francis also notes that it is not possible to sufficiently motivate families to strengthen the conjugal bond and fill their shared life with meaning only by emphasis on doctrinal, bioethical and moral issues without the support of opening up to grace. On the other hand, he makes the case for presenting 'marriage more as a dynamic path to personal development and fulfilment than as a lifelong burden' ${ }^{22} \mathrm{He}$ speaks for respecting 'the conscience of the faithful, who very often respond as best as they can to the Gospel amid their limitations and are capable of carrying out their own discernment in complex situations. We have been called to form consciences, not to replace them, ${ }^{23}$ he concludes. This attitude of the Pope is at the same time his primary starting point for developing the notions of the particular form of pastoral practice, which can in many respects be also applied to social work.

\section{Pastoral care close to the human being}

Pope Francis offers particular incentives for the form pastoral practice ought to take in the sixth chapter of Amoris laetitia. Already in the introduction he notes that he does not intend to present a teaching on the pastoral care of families, but merely to generally outline some new pastoral methods. These should be elaborated on by individual communities, which would in accordance with the doctrine of the Church present more practical and efficient proposals taking into account local needs and requirements. ${ }^{24}$ This statement is an early signal of important emphases characterising the Pope's notion of the form pastoral practice ought to take, namely relativising Roman centralism and support for a subsidiary model of pastoral responsibility. This means, among others, 'that not all discussions of doctrinal, moral or pastoral issues need to be settled by interventions of the magisterium, ${ }^{25}$ or also that there is not just one answer to all questions. The Pope underscores that 'unity of teaching and practice is certainly necessary in the Church, ${ }^{26}$ which, however, 'does not preclude various ways of interpreting some aspects of that teaching or drawing certain consequences from it [...] [since] every general principle ... needs to be inculturated, if it is to be respected and applied.' ${ }^{27}$

The Pope's accents derive from his frequently repeated idea of the supremacy of time over space. In this context he speaks of the tension between fullness and limitation, which one must learn to bear. According to the Pope, space, or rather the attitude 'have it all now', represents limitation. Time, on the other hand, 'has to do with fullness as an expression of the horizon which constantly opens before us. ${ }^{28}$ The Pope regards the principle when time is superordinate to space as the principle of progress, since it 'enables us to work slowly but surely, without being obsessed with immediate results. ${ }^{29}$ With respect to marriage and family, this means perceiving the dynamics and complexity of the process of these institutions' formation towards the ideal which opens up before them as a reachable perspective. Marriage and family are a human reality, which is not an ideal but a complex which is in many respects in need of salvation. From this point of view

\footnotetext{
Ibid., 38 .

Ibid., 37.

Ibid.

Cf. Amoris laetitia 199

Ibid., 3.

Ibid.

Ibid.

Evangelii gaudium 222

Evangelii gaudium 223.
} 
'families are not a problem; they are first and foremost an opportunity. ${ }^{30}$ The broad view of the complexity of the life realities of marriage and family presented by the Pope stimulates pastoral care which is not reduced to the mechanical application of norms. It may only be carried out by competent responsible persons (pastoral workers, priests, the local bishop) as a creative process of mediation between the particular human beings, their life situation and the doctrine of the Church. ${ }^{31}$ That also presupposes that the thinking of pastors and theologians, if faithful to the Church, honest, realistic and creative, will help us to achieve greater clarity' in doctrinal, moral, spiritual, and pastoral questions. ${ }^{32}$

The central motive of pastoral work ought to be joy, or joyful love, which is linked to mercy. This is the golden thread of the present Pope's pastoral theology, which interlaces his pastoral texts. The Christian message concerning the family ought to be truly a joyful message, which responds to the desire for a family, which is alive especially among young people. ${ }^{33}$ The Pope wants to motivate Christian families 'to value the gifts of marriage and family, and to persevere in a love strengthened by the virtues of generosity, commitment, fidelity and patience. ${ }^{34}$ At the same time he wants 'to encourage everyone to be a sign of mercy and closeness wherever family life remains imperfect or lacks peace and joy. ${ }^{35}$

The text of Amoris laetitia is free of all dogmatism or antagonisms. It is not limited to prohibitions and doctrinal definitions. The Pope explicitly warns against 'a cold bureaucratic morality'36 against applying 'moral laws to those living in "irregular" situations, as if they were stones to throw at people's lives. ${ }^{37}$ He presents a text characterised by simplicity, with a positive and encouraging accent. The Pope's main purpose is to point out the most important aspect of pastoral care, which is proclaiming the joyful message of Jesus Christ for the sphere of marriage and family. In practice this means that shepherds are to listen with sensitivity and peace and with the honest desire to enter the drama of human beings and come to understand their point of view, and in that way to help them to live better and become aware of their place in the Church. ${ }^{38}$

The pastoral perspective and its accents, as presented by Pope Francis in Amoris laetitia, can ultimately be compressed into three words: guidance, discernment and integration.

The Pope underscores the pressing need for guidance before contriving marriage, as well as in the marriage's course, especially in its early phases. He regards reducing marriage preparation to a short-term catechesis on faith and the conjugal life immediately preceding the wedding ceremony as insufficient. Passing over the fact that, as he observes, every human being is de facto preparing for marriage since birth, ${ }^{39}$ he emphasises the need for long-term marriage preparation realised by the local community, which is to offer special programmes of immediate marriage preparation. In line with the accent he places on the importance of emotional life in marriage, or conjugal love, as he exclusively presents it in the $4^{\text {th }}$ chapter of Amoris laetitia, he notes that the wedding ceremony ought not to be seen as the end of the journey. Marriage is a vocation which

30 Amoris laetitia 7.

31 Cf. Marianne HEIMBACH-STEINS, Denise MOTZIGKEIT, Janine REDEMANN, Karolin FRERICH and Petr ŠTICA, Familiale Diversität und pastorale Unterscheidung. Eine theologisch-ethische Analyse zum nachsynodalen Schreiben Amoris laetitia, Sozialethische Arbeitspapiere des Instituts für Christliche Sozialwissenschaften 5/2016, Münster: Institut für Christliche Sozialwissenschaften, p. 12.

Cf. ibid., 1.

Ibid., 5 .

Ibid.

Ibid., 312.

Ibid., 305.

3 Cf. ibid., 312.

39 Cf. ibid., 208. 
ought to be discovered and developed throughout one's life. It means that pre-marital pastoral care, as well as pastoral care of married couples, is to focus on the marital bond and at the same time help the couples to not only deepen their love, but also to learn to overcome problems and difficulties. ${ }^{40}$ The couples also ought to obtain necessary information concerning 'places, people and services to which they can turn for help when problems arise. ${ }^{31}$

As already mentioned, the Pope places an emphasis on guidance, especially on guiding married couples in the first years of common life. In line with the documents summarising the results of debates at the two synods of bishops on the family, Pope Francis underlines the need for pastoral guidance, which had already been mentioned by earlier magisterial documents. While previously this had meant 'assistance on the spouses' path to coping with the tasks entrusted to them, especially responsible service to life, and living a Christian life, ${ }^{42}$ Pope Francis also emphasises the importance of guiding them to emotional maturity, or maturity of their relationship. ${ }^{43}$ In this a special part can be played by more experienced married couples, who can provide significant help in the form of couples guidance, as elaborated, for example, by the book Guiding Young Married Couples to a Mature Relationship. ${ }^{44}$ The conclusions reached in that book are consonant with the position of Pope Francis, who points out that in the marital union 'the spouses assume an active and creative role in a lifelong project. ${ }^{35}$ This includes the constant exercise of mutual love, 'an interplay of give and take, for the good of the family. ${ }^{46}$ The point is not that 'there will be no winners and losers, but rather two winners... each home is unique and each marriage will find an arrangement that works best. ${ }^{37}$ Last but not least, upon presenting some of the sources of help in the pastoral care of families Pope Francis notes that it 'has to be fundamentally missionary, going out to where people are. We can no longer be like a factory, churning out courses that for the most part are poorly attended. ${ }^{48}$

Regarding crises or crisis situations in families, Pope Francis formulates the requirement of discernment and integration. He first of all notes that 'each crisis has a lesson to teach, ${ }^{49}$ which one must learn to discern..$^{50}$ The Pope enumerates various kinds of crises, which naturally arise in married and family life, such as, for example, the crisis of the 'empty nest' or the crisis brought about by the aging of the spouses' parents. ${ }^{51}$ The Pope underscores the importance of pastoral assistance, which most of the persons who need it do not seek, because 'they do not find it sympathetic, realistic or concerned for individual cases. ${ }^{32}$ Regarding other situations, which need to be discerned with care, such as the pastoral guidance of separated, divorced and deserted married persons, pastoral care ought to be characterised by personal closeness. It ought to be perceptive to the pain of the interested parties, especially children. Such care ought to include reconciliation and mediation, expert counselling centres ought to be provided. Those who find themselves in problem situations ought to be integrated into the Christian community and parish pastoral

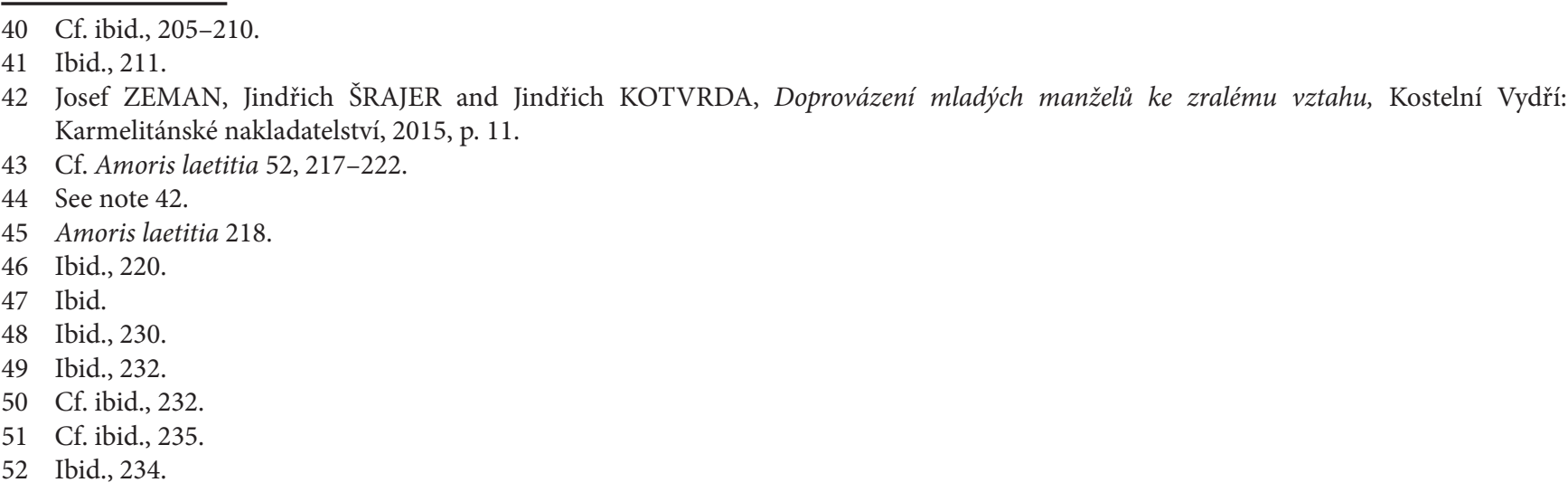


institutions. ${ }^{53}$ The Pope also notes the situation of families, in which a member expresses a homosexual orientation, or the situation brought about by the death of a family member and its impact on the bereaved. In both cases he speaks for a sensitive approach, due attention and good will towards the persons concerned. ${ }^{54}$

\section{Discernment in conflict situations and integration}

While guidance is concerned with discovering and nurturing the positive expectations and prospects in the guided person, the requirement of discernment and integration primarily concerns conflict and problem situations and solving them. In this sense it regards not only pastoral practice, but eminently also the practice of social work. The primary focus here is appropriate ethical discernment in situations of collision.

As has already been indicated above, in Amoris laetitia Pope Francis is not offering simple solutions to dubious issues of dogma, moral theology, canon law or pastoral theology. His emphasis is placed on subsidiary fulfilment of responsibility at all levels of pastoral assistance, with appreciation for the personal conscience of the individual as being capable of discernment. The Pope's position is corroborated by biblical evidence, rooted in the Ignatian spirituality proper to him and theologically linked to the scholastic tradition. It means careful discernment of individual situations and the requirements implied by them and appropriate pastoral-ethical decision-making at the respective local levels. ${ }^{55}$ For pastoral practice, but in a transposed sense also for social work, this means emphasising the personal responsibility of pastoral and social workers, which must not hide behind the strict application of an ethical norm or law or behind the institution of the Church $^{56}$ or the criteria or standards set by the helping organisation in social work. In the concept of pastoral perspectives presented by Pope Francis, emphasis is placed on personally involved interaction between the pastoral worker, the spouses and the family; in the sphere of social work this can be applied to the interaction between the social worker and the client or clients (spouses, parents, etc.). It is not sufficient merely 'to consider whether or not an individual's actions correspond to a general law or rule. ${ }^{57}$ According to the Pope, this would be not only reductive but also insufficient with respect to the human perspective. It would be the attitude of a 'closed heart', ${ }^{5}$ of arrogantly and superficially judging difficult cases and wounded families. ${ }^{59}$

According to the Pope, the involved attitude of the helping workers is to be permeated with tenderness. These workers must also learn to 'treat the weak with compassion, avoiding aggravation or unduly harsh or hasty judgments. ${ }^{60}$ If they do not, it means that they are not concerned with the complexity of different situations and do not perceive the life and suffering of the persons involved in those difficulties. He also regards definitively condemning a human being as inadmissible. ${ }^{61}$ While these emphases without doubt find justification in the biblical and Christian tradition, it is impossible not to mention the risks faced by helping workers, such as, for example, the 'messianic complex' or burn-out syndrome. The Pope does not explicitly mention these risks,

53 Cf. ibid., 241-246.

54 Cf. ibid., 250, 253-258.

55 Cf. Marianne HEIMBACH-STEINS, Denise MOTZIGKEIT, Janine REDEMANN, Karolin FRERICH and Petr ŠTICA, Familiale Diversität und pastorale Unterscheidung, p. 1.

56 Cf. Amoris laetitia 305.

57 Ibid., 304.

58 Ibid., 305.

59 Cf. ibid., 305.

60 Ibid., 308.

61 Cf. ibid., 296. 
or the possible personal limits of helping workers, although the overall context of his text implies that he does perceive the limitation of human responsibility, as it is constituted by the human being's relationship to God. The primary responsibility for everything is proper to the Creator God who provides assistance and solace to the human being. That also holds when the Pope challenges the helping workers to stop seeking personal or social hideaways, which enable them to maintain a distance from the human drama. When one dares to come into contact with the particular existence of others, he experiences the power of tenderness. ${ }^{62}$ But on the other hand, 'whenever we do so, our lives become wonderfully complicated. ${ }^{63}$

The Pope's pastoral exhortations to guidance, discernment and integration in pastoral practice and in a transposed sense also in social work comprises the requirement he repeatedly stresses, namely that the process of maturation be respected in all human beings, which requires the helping workers to be available, persistent and patient. But in the practice of social work, social workers can encounter 'external obstacles' preventing them to fulfil the requirement, often even against their good will. From this point of view it is often excessive administrative burdening placed on the social workers - the necessity to fill in forms, work out protocols from meetings, etc. The question arises to what extent this is a problem of the system and to what extent it can in some cases be a kind of excuse, when the social worker lacks courage or willingness to guide problem clients on a long-term basis. Some institutions even ban deeper conversations with clients and long-term guidance.

The Pope's pastoral exhortations, as indicated above, conceal a pre-meditated theological position drawing on the wealth of the Christian tradition and the doctrine of the Church. Apparently, this wealth has as yet not been sufficiently appraised; it has not become a matter of the mainstream. The Pope appeals especially to Thomas Aquinas and to his predecessor in office, John Paul II. But the Pope's attitudes are also corroborated by contemporary authors, such as, for example, the German ethicist Konrad Hilpert, who reflects on the individual aspects of personal responsibility highlighted by ethics in an exclusive manner. ${ }^{64}$

Pope Francis bases the necessity to respect the maturation process in all individuals, which presupposes a familiarity with his particular conditions and his level of understanding the objective requirements of the law, on the so-called 'law of gradualness' as formulated by John Paul II. Together with him, he notes that this does not mean a 'gradualness of law'. The law loses nothing of its validity ${ }^{65}$ It merely makes provision for the different degree of responsibility in the individual cases, since the 'consequences or effects of a norm need not necessarily always be the same. ${ }^{66}$ In other words, the point is not to compromise the demands of the Gospel, but to be aware of the mitigating circumstances. In practice, this means that all those who find themselves in an 'irregular' situation with respect to an objective requirement of the law need not necessarily be living in a state of mortal $\sin { }^{67}$ The principal emphasis is that even if the particular person is clearly familiar with the norm, that person can still find it very difficult to understand the values involved in the moral norm 'or be in a concrete situation which does not allow him or her to act differently and decide otherwise without further $\sin ^{3}{ }^{68}$ since 'factors may exist which limit the ability to make

62 Cf. ibid., 308.

63 Ibid., 308.

64 Cf. Konrad HILPERT, Zentrale Fragen christlicher Ethik: Für Schule und Erwachsenenbildung, Regensburg: Friedrich Pustet, 2009.

65 Cf. Amoris laetitia 295.

66 Ibid., 300.

67 Cf. ibid., 301.

68 Ibid., 301. 
a decision. ${ }^{69}$ With reference to the Catechism of the Catholic Church, Pope Francis notes that 'imputability and responsibility for an action can be diminished or even nullified by ignorance, inadvertence, duress, fear, habit, inordinate attachments, and other psychological and social aspects, among which he lists 'affective immaturity, force of acquired habit, conditions of anxiety or other psychological or social factors. ${ }^{70}$

In this way Pope Francis clearly shifts the earlier accent in evaluating a moral act from its fact towards the subject of action, to reflecting on his/her dispositions. Thereby he places emphasis on the responsibility of pastoral workers, whose task it is to assist human beings in the process of conscience maturation by honestly discerning in individual situations. This comprises, among others, the recognition that although a certain particular situation does not conform to the general requirements of the Gospel, yet in the given circumstances it may be a case of magnanimously responding to God within the existing human limitations, without thereby doubting an openness to new phases of growth and new decisions, which will allow the person to reach the desired ideal. ${ }^{71}$

Pope Francis bases the abovementioned paradigm change away from evaluating an act according to its facts to considering the dispositions of the acting subject on Thomas Aquinas's virtue ethic. Following the Aristotelian tradition, Thomas Aquinas places virtue in the middle between two extremes, and also between the extremes of rigorism and laxism. In that, he distinguishes between speculative and practical reason. While speculative reason derives consequences in a strictly logical manner from the principles, in the practical sphere this is not possible. There, the set objective norms are not perfect; they represent a certain level of generalisation. They are incapable of grasping all of the circumstances of life. Therefore these norms cannot be applied by means of logical deduction, but through the virtue of wisdom, or prudence. This, according to Thomas Aquinas, becomes reason's criterion of action. Thus, the virtue of wisdom or prudence is the foundation of all virtues, applying the intellectually cognised end of the human being, i.e., the good, in particular situations. ${ }^{72}$ With these references to Thomas Aquinas, Pope Francis refutes the criticism that has been raised against his attitudes as formulated in Amoris laetitia, which labels them as situation ethics. With reference to Josef Pieper, for whom wisdom is equivalent to situational conscience, Walter Kasper notes that this has nothing to do with situation ethics, as wisdom does not derive norms from situations, creates no norms, but on the contrary presupposes them and applies them to particular situations. ${ }^{73}$ This is also explicitly expressed by Amoris laetitia, where the Pope says that 'what is part of a practical discernment in particular circumstances cannot be elevated to the level of a rule. That would not only lead to an intolerable casuistry, but would endanger the very values which must be preserved with special care. ${ }^{74}$

\section{Conclusion}

Pope Francis's apostolic exhortation Amoris laetitia, which summarises and elaborates upon the conclusions of two synods of bishops on the family, offers a number of incentives, both for the form ecclesial pastoral practice ought to take and for the sphere of social work, despite the dif-

69 Ibid.

70 Ibid., 302, or Catechism of the Catholic Church 1735, 2352.

71 Cf. Amoris laetitia 303.

72 Cf. Summa theologiae I/II, q. 64, art. 1; De Virtutibus, art. 13; Summa theologiae I/II, q. 57, art. 4; II/II, q. 47, art. 2 s. c.; art. 6. Cf. on this Walter KASPER, „Amoris laetitia“: Bruch oder Aufbruch?, p. 726.

73 Cf. ibid.

74 Amoris laetitia 304. 
ferences between these two spheres of human practice. Pastoral work, or the role of the pastoral worker, is determined by the specific culture of the Church's life and mission, which is to initiate the human being into a relationship with God. For the pastoral worker, this means assisting the human being, especially in the form of guidance, in realising one's personal vocation, which includes discovering, discerning and fulfilling ethical and spiritual requirements and needs, which are to guide the person to a mature and successful life. In marriage and family this involves especially increasing the quality of the conjugal relationship, and discerning and fulfilling the conjugal and family responsibility, as well as integration in the community of the Church, which nurtures the person(s) and becomes for them a source of vitality (grace) and constant renewal.

The role of the social worker is different, not only, as noted in the introduction to this paper, in that social work focuses only on the problem phenomena of marriage and family, but also in that it is based in the fairly heterogeneous secular culture. Its primary goal is not an effort to anchor the client(s) with respect to an ideology or to some values, albeit it does reflect on the issue of values, but facilitating his (their) social functioning and fulfilling the associated requirements and needs.

The question raised in the introduction to this paper, namely whether and to what extent can the incentives contained in the documents of the synods of bishops held in autumn 2014 and 2015 and in Pope Francis's post-synodal apostolic exhortation Amoris laetitia be inspiring also for social work, can be without doubt answered affirmatively on the principal or methodological level. Let us first recall the emphasis on the personal responsibility of pastoral and social workers noted above, which cannot hide behind the strict application of an ethical norm or law, behind the institution of the Church, ${ }^{75}$ or behind the criteria or standards set by a helping organisation in the sphere of social work. Another useful incentive may be the emphasis on a personally involved interaction between the pastoral worker, the spouses and the family, or between the social worker and client(s), which is governed by the logic of sympathy for those who are weak, avoids prosecuting them, condemning them, or making overly harsh and hasty judgments, respects the process of human maturation and is characterised by temporal availability, perseverance and patience. The difference in the pastoral worker's and social worker's 'background' will ultimately mean that while the inadequate attitude of 'judge', criticised in Amoris laetitia, taken by a pastoral worker will raise the question of the consequences of an ethical paradigm, which still persists in the Church and is problematic from the contemporary point of view, in the case of a social worker such an inadequate attitude will be perceived primarily as an ethical professional failure, as a consequence of personal immaturity, or as a consequence of the burn-out syndrome of messianic complex. 


\title{
Selected Impulses of the Synods of Bishops on the Family (2014, 2015) and of the Post-Synodal Apostolic Exhortation Amoris laetitia (2016) for the Helping Professions
}

\begin{abstract}
The paper reflects on some of the assertions of Pope Francis's post-synodal apostolic exhortation Amoris laetitia. It aims to specify the exhortation's impulses for the helping professions, pastoral care and social work. It implicitly addresses the question whether these impulses, deriving from the Christian worldview and assuming it in the interested persons, are of some relevance for secular social work, for which this worldview is neither a condition nor a general standard. For that reason the paper also offers a brief overview of the form and significance of the Christian ethical paradigm in the history of the Church.
\end{abstract}

Keywords: Pope Francis, Amoris laetitia, marriage, family, pastoral care, social work, ethics, accompanying, discerning, integration

\section{Author contact}

Assoc. Prof. Jindřich Šrajer, Dr. theol.

University of South Bohemia in České Budějovice

Faculty of Theology, Department of Ethics, Psychology and Charity Work

Kněžská 8, 37001 České Budějovice

srajer@tf.jcu.cz 